\title{
FANTOMA TRECUTULUI SOVIETIC ÎN SCRIERILE AUTORILOR EMIGRAȚI DIN REPUBLICA MOLDOVA
}

\author{
Emilia STAJILA \\ Universitatea de Stat din Moldova
}

\begin{abstract}
Rezumat. După o perioadă lungă de dominație a unui regim sadic, poporul basarabean a rămas să fie bântuit din generație în generație de fantoma trecutului tragic. Mulți dintre martorii oculari ai ororilor sovietice s-au stins, însă au transmis urmaşilor niște realități și principii. Unii au rămas pentru decenii înainte să fie nişte victime masochiste ale regimului sadic, alții au reușit să vadă din perspectiva adevărului realitățile cumplite care au avut loc în spațiul dintre Nistru și Prut. După destrămarea megasocietății sovietice, Republica Moldova s-a ciocnit cu nesfârșitele crize ale unui stat devenit independent pe neprins de veste. Astfel, cetățenii acestei țări tinere au fost nevoiți să se familiarizeze cu noțiunea de migrație. Lumea a reușit să găsească noi oportunități, doar că acestea au fost cunoscute departe de casă. Migrația şi Occidentul au favorizat, în mare parte, dezvoltarea literaturii contemporane din Republica Moldova chiar dacă mulți dintre scriitori sunt stabiliți în alte țări. Experiența migrației a și scos din majoritatea lor starea latentă în care se afla talentul scriitoricesc. Noile experiențe adaugă teme şi abordări originale, însă fantoma trecutului sovietic se strecoară uşor prin venele tuturor indivizilor ce-și au originea în Republica Moldova.
\end{abstract}

Cuvinte-cheie: Regim sovietic, tendință sadică, migrație, literatura migrației.

Abstract. After a long period of domination by a sadistic regime, the Bessarabian people remained haunted from generation to generation by the ghost of the tragic past. Many of the eyewitnesses of Soviet horrors were extinguished, but they passed on to their descendants some realities and principles. Some remained for decades before being masochistic victims of the sadistic regime, others managed to see from the perspective of truth the terrible realities that took place in the space between the Dniester and the Prut. After the collapse of the Soviet megasociety, the Republic of Moldova clashed with the endless crises of a state that had become independent. Thus, the citizens of this young country had to get acquainted with the notion of migration. People managed to find new opportunities, only they were known far from home. The experience of migration removed from most of them the latent state in which the writing talent was. The new experiences add original themes and approaches, but the ghost of the Soviet past easily seeps through the veins of all individuals originating in the Republic of Moldova.

Keywords: Soviet regime, sadistic tendency, migration, migration literature. 
De veacuri poporul nostru este prigonit și schilodit nu doar fizic, ci și moral, cultural. Reperele istorice încercă să trimită generațiile de acum în galeriile monstruoase ale realităților construite de regimurile sadice. Absența de libertate care a produs destine frânte ale basarabenilor este un rezultat al tendințelor de dominare pornite din mințile nevrotice ajunse la putere. Aceste conștiințe tulburate au transformat lumea într-un laborator de experimentare ale tendinţelor sadice de care dădeau dovadă. Ca urmare, eul puternic a reușit să reziste torturilor, iar eul slab a devenit masochist (astfel poate fi explicată nostalgia bolnavă și dependenţa unora față de amintirile frumoase din URSS). Ceea ce unii numesc „cea mai bună perioadă din viață”, ,cel mai bun regim” și cei mai „dulci ani”, de fapt, realmente, psihanalistul german Erich Fromm numește tendințe masochiste care „sunt deseori resimțite ca fiind în mod clar patologice sau iraționale”. (Fromm, 1998, p. 127). Psihanalistul evidențiază că ,unele dintre cele mai frecvente forme în care apar tendinţele masochiste sunt sentimentele de inferioritate, de neputinţă, de insignifianță a individului". Aceste ultime porniri disperate pot fi întâlnite la multe victime ale regimului. Chiar dacă personale în cauză s-au aflat ,,călare pe cal” (sau pe o ,Volgă" neagră de cele mai dese ori) în timpurile sovietice, nu sunt, de fapt, decât niște jertfe ale sadismului majoritar.

Oricum fantoma trecutului sovietic va bântui încă mult timp inimile basarabenilor. Unii dintre ei au fost și au rămas niște masochiști mediocri, alții reprezintă generația de eu care nu s-a frânt totalmente, ci a reușit să renască din gheaţa siberiilor. $\mathrm{Cu}$ regret, voinţa axială de a evita ipostaza masochistă a avut urmări grave pentru majoritatea persoanelor de pe teritoriul dintre Nistru și Prut, însă caracterul puternic și vrednicia le-au rămas intacte, ba mai mult, s-au fortificat până la nivelul cromozomilor. Astfel au luat naștere generațiile demne ce continuă să rămână rezistențe la toate șmecheriile istoriei fără a deveni sadiști sau masochiști. Cât de mult nu s-ar încerca o mimare a unei amnezii colective, chiar și peste treizeci de ani după ultima suflare a imperiului sovietic, curge prin vene izul amărăciunii şi al tragismului prin care au trecut oamenii și firele de iarbă dintre Nistru și Prut. Probabil această stare de combustie interioară nu e decât o molimă transmisă genetic, o continuă mocnire a ,sentimentului risipirii ontologice și al căderii Basarabiei în captivitatea unei puteri agresive, brutale, primare” sau eterna „forţă oarbă, devastatoare, o energie colectivă nefastă, inexorabilă” (Țurcanu, 2017, p. 161). $\mathrm{Nu}$ este dorul bolnav de regim, ci e doar o deplângere a existenței cu doar câteva rectificări în scenariul propus de predecesori. Durerea acută nu se temperează pe parcursul anilor, ba chiar se transmite din tată-n fiu. Martorii oculari ai războiului, foametei și Gulagurilor încet, încet și-au găsit hodina. Au rămas copiii și nepoții lor care poartă cu ei și la capătul lumii algezia implantată în ADN, știind doar că ea este „corolarul”, produsul unei istorii de 200 de ani cu o geografie labilă de margine, cu 
metamorfoze și, în deosebi, pseudomorfoze cauzate de constrângerile și influența fatală a centrului imperial rusesc" (Țurcanu, 2017, p. 161).

Între timp s-a accelerat migrația, având efecte dramatice asupra societăţii care și-a gonit proprii cetățeni, forțele de muncă, mințile luminate, capabile să scoată țara din impas. Părăsirea gliei-mamă este un proces foarte cunoscut pentru poporul care încearcă să păstreze unica avere - teritoriul dintre Nistru și Prut. Unii se luptă politic, economic, iar alții iau arma fidelă - condeiul și încearcă să facă știut printre popoare acest pământ trecut prin foc și prin sabie. Pe timpuri, cărțile erau scrise acasă, sub un copac ce miroase a viață, apoi se scria în Siberia despre ororile trăite, un gen de jurnale despre un fel de biletele intr-o singură direcție sau, mai binezis, plângerile care duceau oamenii cinstiți în direcția morții. După o vreme, cei care rămăsese, scriau despre foamete și sărăcie, apoi despre ,iluzia sovietică”, în anii 90-2000 iarăși despre greutăți și sărăcie, treptat, trecând spre emoțiile de la prima întâlnire cu Occidentul care era un fel de pământ al speranțelor pentru toți basarabenii. Acum încă se mai scrie - despre migrație, despre alte culturi, alte mentalități, însă, chiar de se scrie din diasporă, nu se uită de glia strămoșească, de oamenii care au dat naștere altor vieți, în pofida regimurilor, ba mai mult, chiar în ciuda lor.

În marea majoritate a literaturii migrației se pot atesta urme directe sau indirecte ale istoriei poporului basarabean. Printre sutele de pagini, miile de cuvinte, găsim măcar un indiciu cât de minuscul care reprezintă o valoare istorică, fie că e amintire, regret, dor sau un regionalism cu efect de prăjitură proustiană.

Fiecare emigrant are un talisman al său, un testimoniu ce-1 reprezintă în timp și în spațiu. Unii își iau câteva fotografii de-ale părinților și bunicilor, o icoană, un medalion (dacă nu a fost dat în schimb pentru o felie de pâine pe vremea foametei) sau chiar un ac precum acela despre care ne relatează scriitoarea Tatiana Țâbuleac în Fabulele sale: „Acul pe care-1 am de la mama, iar ea - de la mama ei. Acul și pozele din copilărie - atât mi-am luat când m-am mutat la Paris. Bunica îl ținea înfipt în cel mai înalt loc din casă, pe un păretar, ca nu cumva să îl iau eu și să îl pierd. Peste o palmă erau icoana și candela [...] Când în iulie ,49 au venit comuniștii să îmi deporteze bunicii în Siberia, soldații au fost umani. Le-au dat zece minute ca să-și ia cele mai importante lucruri din casă. O icoană, nişte bani și acul, toate le-a luat bunica.

- Unde te duci tu, bani și icoană nu-ți trebuie, i-a zis omul legii. Acul poți să-1 iei [...] În Siberia acul a trăit șapte ani, apoi s-a întors acasă, la pieptul bunicii. Ca un sugar. Ca o inimă exterioară [...] Apoi s-a retras. Mai întâi pe peretele stăpânei sale. Apoi pe cel al mamei. Iar acum în cutia mea, la Paris".

Precum obiectele rămase despre care am menționat mai sus și memoria suferinței își continuă traseul ei din generație în generație. Acea epopee sadică 
inițiată de regimul sovietic a lăsat urme groaznice și de lungă durată, doar că în durerea genetică pe care o simt copii și nepoții rămași să deplângă soarta cruntă a Basarabiei.

Scriitoarea Lilia Bicec-Zanardelli în ambele sale romane Testamentul necitit și Lagărul 33 evidențiază ororile cumplite ale regimului sovietic și teroarea simțită în acele vremuri. Protagonistul romanului Lagărul 33, Vittorio Monttini, prizonier de război de origine italiană, după ce supraviețuiește în masacrul de la Bălți și este deportat în Siberia împreună cu familia care la salvat, este de fapt o mostră care definește soarta multor basarabeni din acele timpuri. Pe atunci, toată societatea (dacă o putem numi societate) era divizată în două. O parte poate fi întruchipată de reprezentanții săi cum ar fi Vittorio, Maria, Ștefania și alte zeci de milioane de oameni deportați pe nedrept, iar cealaltă parte a societății era formată din inși precum locotenentul Kapustov, cel ce avea o plăcere imensă când ordona Rastrel! (Împușcat!), cădea în euforie, se simțea erou al patriei şi avea o senzație teribilă a abandonului când nu mai avea pe cine tortura și împușca. Durerea de atunci răzbate și astăzi de sub straturile timpului, mai ales ea dă târcoale pe la inimile urmașilor oamenilor care au avut de suferit, pe când urmașii lui Kapustnikov și ai celor care au făcut nelegiuiri și acte de sadism au continuat și mai continuă programul străbunicilor prin cruzime, îmbogăţiri ilicite și sadism dacă nu fizic, măcar moral. Este instabil termenul de valabilitate al expresiei atât de reuşite: „Unii se tem de stafii, alții de hoți și toți - de enkavediști” (Bicec-Zanardelli, 2018, p. 51). Această frică s-a întipărit în ADN, alături de chinuri și tristeți. Volens nolens se strecoară printre rândurile scriitorilor fantoma sovietismului, dezlegând adevăruri pe care nu le-au putut pronunța cu voce tare câteva generații, însă, de la alt capăt al Europei, peste mări și țări, după calvarul istoriei și al emigrației, apar realități și povești ale multor familii. Abia vlăstarele pot să vorbească despre tot ce s-a întâmplat cu vechile rădăcini.

În Testamentul necitit, în unele din scrisorile sale, pe lângă propria odisee de emigrant, Lilia Bicec-Zanardelli prezintă într-un mod instructiv repere din istoria Basarabiei îmbinate cu povestea de viață a bunicilor și părinților ei care au fost martori oculari ai evenimentelor sfâșietoare ce au avut loc, dar și cu propriile probleme încă din timpul când era elevă și de nenumărate ori a avut de suferit din cauza că era din neam de culaci: „...îmi venea să mă ridic strigând: Noi nu suntem culaci, nu suntem dușmani, noi suntem jertfele comunismului pe care țineți să-1 elogiem pe la manifestații!” (Bicec-Zanardelli, 2018, p. 79). Autoarea își amintește de toată suferința produsă de regim, însă și de imposibilitatea de a te lupta cu acel bătrân balaur, ce a fost născut din mințile nebune ale unor psihopați ajunși la putere: „Îndreptându-mă spre casă îmi aminteam cuvintele lui tata: Trebuie să tăcem, să ne supunem, căci am rămas prea puțini, iar regimul e aspru, Siberia e dură, frigul 
coboară mai jos de $40^{\circ} \mathrm{C}$ și multe morminte de basarabeni au rămas în paragină. Acolo zace și bunelul tău decedat la 54 de ani” (Bicec-Zanardelli, 2018, p. 79). Foarte mulți bunici, părinți, frați, surori, copii și-au găsit locul de veci atât de departe, la capătul lumii, unde au fost duși de o tumoare roșie care a reușit să distrugă zeci de popoare. Scriitoarea își încheie unul dintre răvașele adresate copiilor săi cu următoarea frază: „, Acel regim stalinist-comunist a lăsat o amprentă dură asupra lor (bunicilor), trecându-i încă tineri în lumea celor drepți, a lăsat o umbră neagră și asupra copilăriei voastre, lipsindu-vă de căldura și sfatul buneilor..." (BicecZanardelli, 2018, p. 79) Aceste triste urme au o continuitate infinită, strecurându-se atât de reuşit în ADN-ul spiritualist al basarabenilor.

În pofida carnagiului care durase ani buni, comunismul a reușit să plaseze în niște tipare viziunile oamenilor. Chiar și cei mai iluminați, mai aveau detașări ideatice de realitățile oribile, pe alocuri crezând că lumina vine doar dinspre așa-zisa „atotputere" a URSS. Autoarea recunoaște în ce hal ajunsese mentalitatea oamenilor după ce li s-au spălat creierii de către regim și teroare: „Câte țări interesante sunt pe globul pământesc, iar eu eram atât de mărginită, crezând că toată lumea e Uniunea Sovietică, iar celelalte țări de pe hartă erau vai de capul lor!” (Bicec-Zanardelli, 2018, p. 69) fiecare homo sovieticus nici nu putea să-și imagineze că există viaţă dincolo, adică după hotarele URSS, iar despre viața de dincolo nici nu se mai discuta, deoarece au reușit să distrugă totul, până și locurile sfinte unde își găseau refugiul basarabenii asupriți și prigoniți, însă dornici de spiritualitate. Psihanalistul Mircea Blajin (originar din Republica Moldova, stabilit în Franța) în eseul biografic Culoarea Frontierelor reușește să evidențieze foarte bine acest aspect: „Mitul marxist-leninist trebuia să înlocuiască mitul religios. În pofida mai multor decenii de bulversare a ordinii sociale cu dezrădăcinări și permutări demografice vizibile și astăzi, după un sfert de secol de aşa-numită independență a Republicii Moldova, populația și-a păstrat totuşi originalitatea. Spiritualitatea și-a jucat rolul primordial prin intermediul tradițiilor, culturale, artistice, religioase. O metaforă e binevenită aici: „Când rădăcinile sunt tăiate în pământ, ele urcă spre cer” (Blajin, p. 2018, 112-113).

Totuși, odată cu perestroika s-a iniţiat un proces de diluare a minților înrobite și o criză imensă care a durat ani buni, iar ecoul poate fi distins și acum. După treizeci de ani de independență a Republicii Moldova mulți nu pot percepe: capul plecat nu doar că nu vede soarele, însă riscă foarte ușor să fie tăiat. Oricum a început să se înțeleagă nivelul incomensurabil al coșmarului care s-a petrecut atâtea decenii. Primul val de emigranți care au plecat în Occident ,au sondat” un ,,departe” total necunoscut, un „exotism” cultural, o corectitudine politică și socială pe care le auziseră cândva, demult, de la cineva, ca pe niște mituri. Apoi au început un trai ca după un somn adânc și au descoperit că tot ce a fost până la viața de imigrant, 
nu era decât un coșmar al existenței într-o țară distrusă de regimuri. Indubitabil că după atâtea decenii petrecute în frică și teroare, toți cei care își au originea în Basarabia vor purta în propriul sânge amintiri, crâmpeie de istorie, de cultură ce țin de perioada regimului stalinist-comunist.

Lecturând operele scriitorilor emigrați din Republica Moldova (Lilia BicecZanardelli, Tatiana Țâbuleac, Liliana Corobca, Olga Căpățână, Lilia Calancea, Lucreția Bârlădeanu, Varvara-Valentina Corcodel, Jana Chisăliță Mușat, Vitalie Vovc, Mircea Blajin, Iurie Bojoncă și alții) vom atesta reminescențele sovietismului, fie că acestea vor fi reprezentate de niște rusisme, amintiri, momente biografice, reflecții asupra existenței sau vom putea distinge printre rânduri ceea ce nu s-a spus niciodată despre ororile regimurilor sadice care au dominat și au sfâșiat Basarabia. Fantoma trecutului sovietic va bântui multe decenii, topindu-se pe parcurs și în sângele generațiilor care vor urma.

\section{Referințe bibliografice:}

1. BICEC-ZANARDELLI, Lilia. Testamentul necitit. Scrisorile unei mame plecate la muncă în Occident. Chișinău: ed. Cartier, 2018.

2. BICEC-ZANARDELLI, Lilia. Lagărul 33. Chișinău: ed. Cartier, 2019.

3. BLAJIN, Mircea. Culoarea frontierelor. Chișinău: ed. Cartier, 2018.

4. FROMM, Erich. Frica de libertate. București: ed. Teora, 1998.

5. ȚÎBULEAC, Tatiana. Fabule moderne. Brașov: ed. Libris Editorial, 2016.

6. ȚURCANU, Andrei. Cartea din mâna lui Hamlet. Andrei Țurcanu de vorbă cu Nina Corcinschi. Chișinău; ed. Cartier, 2017. 